\title{
TEACHING ENGLISH USING GOOGLE CLASSROOM AS MEDIA AT MTs ARROHMAN JOMBANG
}

\author{
Khudriyah \\ Prodi Pendidikan Agama Islam, STIT Al-Urwatul Wutsqo Jombang \\ e-mail: azkiabilqis@gmail.com
}

\begin{abstract}
The goal of learning English in junior high school is students can reach the functional level, namely communicating orally and in writing to solve daily problems. This research aimed to describe how teaching English using Google classroom at MTs arrohman Jombang. The research method is qualitative descriptive, interview and observation as instrument. The data then analysed by Miles \& Huberman model. The result are: The process of teaching and learning English: deciding learning objectives, materials, media, and evaluation of all components. The learning objectives were in accordance with the indicators contained in the curriculum. The material conveyed to students were: understanding, function, and application of the past tense in sentences. Using media of power point, pictures, and sheet of students work. The learning method used was questions and answers; the strategy used based on on the students' condition. And the evaluation results dit not achieve the criteria of success. Those students who were able to reach the criterion was only $50 \%$ from A class, and 34\% from B class.
\end{abstract}

Keywords: teaching, English, Google Classroom

\section{BACKGROUND OF STUDY}

The success of educational purpose is based on the success of learning process. Learning process has an important role as an effort to improve education quality with purpose to create meaningful learning; it must optimize learning that is more directed at modernization activities. Something that is told by Thorndike in Nai, that learning occurs through associations or connections formation between sensory experiences, it is a stimulus perception or event and nerve impulses or responses that manifest in the behavior form ${ }^{1}$. He also believes that learning occurs through a series of trial and error experiments or selecting and connecting.

In line with Nai, Sudjana says that the implementation of learning is a process that is arranged in such a way based on certain steps can achieve expected results ${ }^{2}$. Different with them, Bahri \& Zain explain the learning implementation is an activity

\footnotetext{
${ }^{1}$ Nai, Firmina Angela. Teori Belajar dan Pembelajaran Implementasinya dalam Pembelajaran Babasa Indonesia di SMP, SMA, dan SMK. (Yogyakarta: Group Penerbitan CV Budi Utama, 2017) 102.

2 Sudjana. Dasar-dasar Proses Belajar. (Bandung: Sinar Baru, 2010), 136.
} 
that has educative value; it inserted interactions which occur between teachers and students ${ }^{3}$. The Interactions happen because the implementation carried out is directed to achieve certain goals that have been formulated before the implementation of learning begins.

Based on the phenomenon in our country, there are many learning process that achieve their goal, it because of good management. However, currently the world is shocked by pandemic covid-19 which has had an impact on education, especially the educational process that results the quality of learning decreased.

Corona viruses belong to the Nidovirales, the Coronaviriade family, and the Orthocoronavirinae subfamily. The corona virus belongs to the genus Coronavirus and is named after the wreath-shaped protrusion on the viral envelope $e^{4}$.

A pandemic is a global epidemic, which is the spread of an infectious disease to a large number of people over a large geographic area. In addition, it fulfills the WHO requirements/criteria, namely a new disease in a population, where the causative agent of the disease can spread easily and sustainably and infect and cause serious illness in humans. A pandemic is a condition in which an infectious disease spreads rapidly from person to person in many parts of the world. According to the World Health Organization (WHO), the World Health Organization, a pandemic occurs when three conditions are met, namely, the emergence of a new disease in the population, infecting humans, causing dangerous diseases, and the disease can spread easily and sustainably among humans. Since Friday (28/2/2020) WHO has raised the risk status of this corona virus to the highest level due to its rapid spread to a number of countries ${ }^{5}$.Because of the reason, all students in Indonesia must study online, with purpose of breaking the chain of spread of covid 19.

This policy does not only apply in Indonesia, but also in countries that have been exposed to covid-19. With this policy, schools implement teaching and learning

${ }^{3}$ Djamarah, Syaiful Bahri dan Aswan Zain, 2010. Strategi Belajar Mengajar. (Jakarta: Rineka Cipta, 2010), 1.

${ }^{4}$ Li, S., Wang, Y., Xue, J., Zhao, N., \& Zhu, T. (2020). The impact of COVID-19 epidemic declaration on psychological consequences: a study on active Weibo users. International journal of environmental research and public health, 17(6), 2032.

5 Ibadurrahman, Muhammad Alief. Coronavirus Asal Usul, Penyebaran, Dampak, dan Metode Pencegahan Efektif Pandemi Covid-19. Altman, D.G. 1991. Sample Size. In Altman, D.G., Ed., Practical Statistics for Medical Research, Chapman \& Hall, London, 2020), 455-460. 
activities from a distance or online learning (in a network). The implementation of the distance learning process in the era of the covid-19 pandemic, teachers are required to choose and use the right method so that the teaching and learning process continues, in other words, educational interactions are created.

Based on the above explanation, it requires a change management in the class room. One of them is teaching using Google classroom. Google classroom is a learning platform which is able to be intended for the scope of education which is intended to help find a way out of the difficulties experienced in making paperless assignments ${ }^{6}$. It is an application that allows the creation of classrooms in cyberspace. In addition, Google Classroom is also a means of distributing assignments, submit assignments and even assess the collected tasks.

The effectiveness of learning using Google classroom can be seen based on the level of errors made by students when solving the problems given, another thing that becomes a reference for the effectiveness of learning is when the teacher motivates students to study material that has been uploaded to the Google classroom? ${ }^{7}$.

The application of online learning certainly requires readiness for both parties, both from the education staff (teachers) and from students. However, online learning really needs the help of qualified technology so that it can be accessed so that it can facilitate the learning process.

Technology is more than just applied knowledge or engineering as in the traditional understanding of the academic world, but can be seen as a universalistic approach to problem solving techniques ${ }^{8}$.

Information technology is a technique for collecting, preparing, storing, and processing, publishing, analyzing and disseminating information ${ }^{9}$. The application of IT is to identify, collect, and manage data in the form of a database and provide it into useful information for the public in digital packaging that is flexible and easy to share ${ }^{10}$.

${ }^{6}$ Iskandar, A., Possumah, B.T., Aqbar, K., 2020, Peran Ekonomi dan Kenangan Sosial Islam Saat Pandemi Covid-19, Jurnal Sosial \& Budaya Syar'i, 7(7): 625-638.

${ }^{7}$ Iskandar, A., Possumah, B.T., Aqbar, K., 2020, Peran Ekonomi dan Kenangan Sosial Islam Saat Pandemi Covid-19, Jurnal Sosial \& Budaya Syar'i, 7(7): 144.

${ }^{8}$ Yudi Latif, Teknologi sebagai Masalab Kebudayan, Jurnal Ulumul Qur'an, edisi No. 2, Juli 1996, 58-59.

${ }^{9}$ UU RI No 11 Tahun 2008 Informasi dan Transaksi Elektronik, (Jakarta: Sinar Grafika, 2010), 3.

${ }^{10}$ Wahyu Supriyanto, Ahmad Muhsin, Teknologi Informasi Perpustakaan: Strategi Perencangan Perpustakaan Gitital,(Yogyakarta: Kanisius, 2008), 22-25 
Talking about technology seems inseparable from science, because in essence technology is the application of organized science or other knowledge to practical $\operatorname{tasks}^{11}$.

E-learning is a relatively new information technology in Indonesia. E-learning consists of two parts, which is an abbreviation of 'electronic' and 'learning' which means 'learning'. So e-learning means learning by using the services of electronic devices, especially computer devices. Therefore, e-learning is often referred to as an 'online course'. ${ }^{12}$

E-learning is a generic term for all technologically supported learning using an array of teaching and learning tools as phone bridging, audio and videotapes, teleconferencing, satellite transmissions, and the more recognized web-based training or computeraided instruction also commonly referred to as online courses ${ }^{13}$.

Availability of e-moderating facilities where teachers and students are able to communicate easily through internet facilities on a regular basis or whenever the communication activity is carried out without being limited by distance, place, and time. Teachers and students can use teaching materials or structured and scheduled study instructions through the internet, so that both can assess each other to what extent the teaching materials are studied. Students can study or review teaching materials at anytime and anywhere if needed considering that teaching materials are stored on the computer. If students need additional information related to the material being studied, he can access the Internet. Both teachers and students can conduct discussions via the internet which can be followed by a large number of participants, thereby adding to knowledge and broader insight. Changes in students' grades from being passive to active; relatively more efficient ${ }^{14}$.

Google Classroom is also a special application that is used for online learning that can be done remotely, making it easier for teachers to create, group and share

11 Arif S. Sadiman, Peran Teknologi dalam Meningkatkan Mutu Pendidikan Dasar, Jurnal Teknodik, IV, No. 8, Mei 2000. 7.

12 Dewi, Prawiradilaga Salma dan Eveline, Siregar. Mozaik Teknologi Pendidikan, Jakarta : Universitas Negeri Jakarta, 2004), 197-198

${ }^{13}$ Soekartawi, A. Haryono dan Librero. Greater Learning Opportunities Through Distance Education: Experiences in Indonesia and The Philipines. Southeast Journal of Education, (2002).

${ }^{14}$ Mulvihill, RP. Technology Application to Distance Education. Paper presented at the International Symposium on Distance Education and Open Learning organized by MONE Indonesia IDLN, SEAMOLEC, ICDE, UNDP and UNESCO, Tuban, Bali, Indonesia, 17-20 November 1997 
assignments. In addition, teachers and students can carry out learning activities at any time through Google Classroom online classes and students will also be able to learn, listen at any time., read and send tasks remotely. MTs Arrohman Jombang is one of the schools that has used e-Learning as a learning medium where e-Learning activities at the school utilize uses Google classroom. In the learning process students are given material so that students can immediately understand the material presented by the teacher through the Google classroom. In addition, students are also given assignments by the teacher and send the results of their reports to Google Classroom. Google classroom is an alternative to provide material and questions without using print media.

Language has a central role in the intellectual, social, and emotional development of students and is a supporter of success in learning all fields of study. Language learning is expected to help students get to know themselves, their culture, and the cultures of others. In addition, language learning also helps students to be able to express ideas and feelings, participate in society, and even discover and use their analytical and imaginative abilities. English is a tool for communicating orally and in writing. Communicating is understanding and expressing information, thoughts, feelings, and developing science, technology, and culture. The ability to communicate in a complete sense is the ability to discourse, namely the ability to understand and/or produce spoken and/or written texts that are realized in four language skills, namely listening, speaking, reading and writing. These four skills are used to respond or create discourse in social life. Therefore, English subjects are directed to develop these skills so that graduates are able to communicate and discourse in English at a certain literacy level.

The literacy level includes performativity, functional, informational, and epistemic. At the performativity level, people are able to read, write, listen, and speak with the symbols used. At the functional level, people are able to use language to meet the needs of daily life such as reading newspapers, manuals or instructions. At the informational level, people are able to access knowledge with language skills, while at the epistemic level people are able to express knowledge into the target language. Learning English in junior high school is targeted so that students can reach the functional level, namely communicating orally and in writing to solve daily problems, 
while for senior high one it is expected to reach the informational level because they are prepared to continue their education to higher education. The level of epistemic literacy is considered too high to be achieved by the school students because in Indonesia English is as a foreign language.

English subject in junior high school aims to make students have the following abilities. 1. Developing communication competence in oral and written forms to reach the level of functional literacy 2. Having an awareness of the nature and importance of English to improve the nation's competitiveness in a global society 3. Developing students' understanding of the relationship between language and culture. The scope of English subjects in it includes: 1. Discourse skills, namely the ability to understand and/or produce spoken and/or written texts which are realized in four language skills, namely listening, speaking, reading and writing in an integrated manner to reach the level of functional literacy; 2. the ability to understand and create various short functional texts and monologues and essays in the form of procedure, descriptive, recount, narrative, and report. The gradation of teaching materials can be seen in the use of vocabulary, grammar, and rhetorical steps; 3. Supporting competencies, namely linguistic competence (using grammar and vocabulary, sound grammar, writing), sociocultural competence (using expressions and actions of language acceptably in various communication contexts), strategic competence (overcoming problems that arise in the communication process with others). Various ways to keep communication going), and discourse-forming competencies (using discourse-forming tools).

\section{RESEARCH METHOD}

This research used qualitative approach in the form of case study, in this case, the researcher keened to gain deepest information about the English teaching strategy using Google classroom during pandemic of covid-19. The researcher as instrument, digged the information in the field until all data was fulfilled. Using snowball sampling and the data sources from some informants they were English teachers and students of Madrasah Tsanawiyah ar Rohman Jombang.

The data collection technique is through interviews and observation. In testing

the validity of this research data, researchers used several methods of increasing persistence; reading various book references and research results or documentation 
related to the findings studied, peer discussion, and triangulation. Data analysis was performed using the Miles and Huberman model (data reduction, display, and verification / conclusion drawing) ${ }^{15}$.

\section{DISCUSSION}

Based on the results of observations and interviews, it is known that the implementation of Google classroom learning is held 2 times a week, for 2 hours $(2 \mathrm{x}$ 40 minutes) for class VIII MTs Arrohman. The results of observations about the implementation of learning in the pandemic era with tenses material indicate the readiness of teachers that was English teachers started to teach on time, she had sufficient pedagogic competence, she was able to condition her students, and the material delivered is also ready, as well as students, but there were some students who were left behind for various reasons. The results of observations and interviews also showed that there was a notification from the teacher in the What Sapp group regarding the learning that would be carried out. In this case, the teacher gave an announcement to the group members, namely all students of class VIII.

The way of teaching and learning process in the pandemic era was alike as usual learning, the difference is that the teacher does not ask for news or attends students, however, the interaction between teachers and students is quite good. These activities include pre- activities, whilst- activities, and post- activities. In this pre-activity conveyed the learning objectives. In the whilst- activity the teacher conveyed the material (past tense) in detail, starting with using Indonesian so that students understand the teacher's intentions easily, in this case it seen that students are also actively asking if they do not understand. Then in the closing activity (post-activities) the teacher closed the lesson conveying the conclusions of the past tense material has been studied.

The teaching and learning process included several learning components, including: learning objectives, learning materials, learning media, and evaluation of all components have been determined the achievement of learning on tenses material, as follows: The learning objectives of the tenses material include: students are able to

${ }^{15}$ Moleong. J Lexy, Metodologi Penelitian Kualitatif. (Bandung : Remaja Rosdakarya, 2018), 30 
explain the characteristics of the past tense, the verbs used, the adverbs that usually follow, and show past tense forms in sentence paragraphs. It can be said that the learning objectives are in accordance with the indicators contained in the curriculum.

The subject matter is the content of the lessons delivered by the teacher to students during the teaching and learning process. In preparation for teaching the teacher certainly prepared the material to be taught to students. The material conveyed to students includes: understanding, function, and application of the past tense in sentences. In this case the teacher used power point as media; sample sheets of past tense forms in sentences, and student worksheets, as well as student books that were already owned by each student.

The observation results about how the teacher delivered material as follows: the teacher has delivered the material clearly. As the result of an interview with one of the students: Learning in Google classroom is interesting, because it was clearer and simpler. The next student said that he was happy because he was able to observe the use of tenses in the correct sentence. Likewise, the third student said that learning with Google classroom was more detailed than face-to-face. Learning media has a very important role in the learning process. Students will more easily understand the material if it is supported by the media.

Another information resulted from observations that teaching and learning using Google classroom media used by the teacher in the form of pictures. The picture given by English teacher regarding the past tense material was quite clear and easy for students to understand. In this case, the teacher gave pictures about students who leaved school which was numbered as a sequence. Another picture was the teacher gave a picture of the night situation where the students were studying and then told the story in the morning, and all the pictures were serial or sequential. The learning method used was questions and answers method, this method is adapted to the material presented, the circumstances, and the situation of teaching and learning process conducted.

While the strategy used depends on the students' condition. The teacher had provided the previous strategy. However, this strategy can be changed when the teaching and learning process got problems. For example, when the teacher saw a student who was getting tired, the teacher gave a song, or told a funny story. Likewise, 
the material presented or the examples given were simple examples that were often done by students or had happened to students. Assessment of learning outcomes was carried out to determine the student's level in understanding and measure students' ability to understand the material.

The results of the interview with informant A was as follows: "In general the evaluation results were not so good in achieving the criteria of success. Classically, it had not reached the criterion, although individually many students had achieved it." Furthermore, another informant said "Some students were able to follow and absorb the material well but classically had not reached the criterion.

The results of the evaluation carried out after the end of the material were from 30 students who managed to reach the criteria of success (Minimum Completeness Criteria) for class VIII A there were 15 students while those who had not reached it were 15 students. While for class VIII B there were 10 students who had reached criterion, the remaining 19 students had not reached the criterion. With the Minimum Completeness Criteria targeted is 75 , however, they got in fact only 70 .

Totally, the students of A class reached $50 \%$ criteria of success, and B class only reached $34 \%$ from criteria of success. Meanwhile during this pandemic, teachers provided different criteria for completeness from offline schools. The expected target is only $75 \%$ of students from the expected total because during the pandemic it is different from before, considering all teachers, all subjects use the same method, namely online. For Offline School the minimum criterion is that is $85 \%$ students have to be able to reach the minimum criteria of success.

Students' perceptions of teaching and learning using Google classroom can be seen as the results of interviews where on average students said they were happy with Google classroom because even though they studied at home, they were able to study with their friends. Even though they could not meet in person, the attendance list and questions and answers from other friends gave motivation to other students. Related to media used, the students were quite interested in clear images and students were able to catch the message from the image. The strategy used by the teacher was quite interesting because the teacher sometimes also shared funny stories.

While the teacher's perception of teaching and learning using Google Classroom was the teacher is freer to provide material because the time given is more, meaning 
that the teacher can provide material before the lesson begins so that students can learn first.

The supporting factors of learning Google classroom are: fun learning materials where the past tense is the form which happened before telling, the form of stories, and experiences and everyone must have experiences or stories that can remind the past, whether it is fun, sad, or funny stories. From here students are happy and motivated to learn. Besides, students are not bored to learn. As one informant said that he felt comforted after the funny story when he was still studying at elementary school. Likewise, another informant thought that he was amused by his friend's funny story. The factor is student motivation, both extrinsic and intrinsic; these terms support the learning process well, because by having high motivation, learning objectives are easy to be achieved. As the result of an interview with an English teacher that she felt it was helped by the students' motivation. Furthermore, she said that the form of student motivation can be seen from the enthusiasm he told his story, the laughter of students when their friends told their stories. The results of observations also showed that students told stories using Indonesian which were then translated into English.

Parental support for students is also a factor supporting the learning process. As the results of interviews with several parents, for example one of the parents explained the condition of covid-19 made him had to take part in children's learning, whatever the reason, because he couldn't blame anyone. According another parent, she said that the pandemic of covid-19 had hit everyone, so they had to be patient, including accompanying their children while studying. Meanwhile, other informants said that they were worried that their children would not be serious, so online schools must be accompanied, and they are ready to accompany their children any time.

Such advantages of Google Classroom are: it is more effective because students are more receptive to learning and doing assignments through the Google Classroom application. Another advantage is that students can study anytime and anywhere, it doesn't cost much and is very effective. The next advantage is that the material is detailed, the existence of sample images, making it easier to understand the material.

According to one of the informants, the advantages of learning using Google Classroom the material is very simple and easy to understand, because the explanation is very clear and accompanied by a series of pictures. 
While the disadvantage is that in real time, children who have difficulty with material do not direct understand is like learning as usual that is face-to-face, another disadvantage is student discipline is less than hoped.

Inhibiting factors, among others. Internet disruption. Signal is very influential on whether or not the online teaching and learning process is smooth. Many students complained that the signal dropped many times. As the results of interviews with several students, such as: the problem was they often get signal interference, according to other informants learning becomes uncomfortable when the signal breaks. Another inhibiting factor is interference from outside, such as the sound of family members speaking, especially when the teacher was explaining the material. The sound of the television being turned on or the sound of a passing vehicle. As conveyed by several informants about the disruption learning with Google classroom, they said that the sound of family members, people working, or the sound of passing motorbikes.

Based on the above finding it can be analyzed that the teaching and learning using Google classroom has fulfilled the curriculum. The English teacher had taught for two hours. It is in accordance with the government regulation that is the length of learning English is 2 hours of lessons and per hour is 40 minutes ${ }^{16}$.

The English teacher can be said that she is professional because she has professional competence such as readiness in teaching; started to teach on time, mastering the material and could conducive her students when teaching and learning was conducted. Besides, the English teacher also has sufficient pedagogic competence, since the teacher conducted the teaching and learning based the lesson plan had been made.

In teaching English, the teacher implemented the following activities: the preactivity the teacher conveyed learning objectives; in the whilst- activity the teacher conveyed the material (past tense) in detail, starting with using Indonesian to make students understand, the students are also actively asking when they got problem. Then in the post-activities the teacher closed the lesson conveying the conclusions of the material had been studied.

\footnotetext{
${ }^{16}$ Peraturan Pemerintah Nomor 17 Tahun 2010 tentang Pengelolaan danPenyelenggaraan Pendidikan
} 
The several learning components, included in teaching and learning process were: learning objectives, learning materials, learning media, and evaluation. The material was understanding, function, and application of the past tense in sentences. The teacher in teaching used power point as media; sample sheets of past tense forms in sentences, and student worksheets, as well as student books owned by students. And the teacher had delivered the material clearly so that the students were be able to get the point of material.

It means that the teacher has conform the law number 14/ 2005 about teachers and lecturers must have academic qualifications, competencies, educator certificates, physically and mentally healthy, and meet other qualifications required by the higher education unit where they work, and have the ability to realize national education goals $^{17}$.

The above explanation is also can be said that the English teacher has taught effectively. It is in accordance with some experts say: Effectiveness can be interpreted as a parameter to measure success in achieving predetermined goals. The effectiveness is how an organization can utilize resources to achieve operational goals ${ }^{18}$. "Effectiveness is usability, activeness; there is suitability in an activity of someone who is doing a task with an intended target ${ }^{19}$.

The students of MTs arrohman have positive attitude when learning using Google classroom. Many lower learners also had higher motivation in learning. The condition relate to theory of Yew, et.al in which the indicators of learning effectiveness are as follows: positive attitude towards students, since positive attitude can facilitate teachers in carrying out learning activities. Students who have a positive attitude towards a subject will achieve higher learning outcomes compared to students who have a negative attitude towards the subjects they join, and the enthusiasm and mastery of the teacher towards the learning material ${ }^{20}$.

Strengths is higher values existing in everything, while weaknesses is something that make it less than perfect. These advantages and disadvantages are reviewed in

${ }^{17}$ Undang-Undang Republik Indonesia Nomor 14 Tahun 2005 tentang Guru dan Dosen

18 Mulyasa. Pengembangan dan Implementasi Kurikulum 2013, (Bandung : Remaja Rosdakarya, 2014), 25

${ }^{19}$ Slameto. Belajar dan Faktor-faktor yang Mempengarubinya.(Jakarta: Rineka Cipta, 2010), 29.

${ }^{20}$ Yew, E. H., \& Goh, K. Problem Based Learning: An Overview of its Process and Impact on Learning. Health Professions Education, 2016), 75-79. 
terms of material, strategy, and management. These three things are the components of education; they are the objectives/materials of teaching materials, tools/media/learning resources, methods, evaluations, environment, context, management and others ${ }^{21}$.

The advantages here are the added value in learning Google classroom during the covid-19 pandemic era, it seems that Google classroom learning is very effective in the midst of the covid-19 pandemic, students can accept it well, students can do assignments through Google classroom, students can study anywhere and anytime remotely, and it doesn't cost much. Learning Google classroom in the covid-19 pandemic, with past tense as material is very interesting for students because it creates a new learning atmosphere that makes it easier for students to study independently.

The media used by English teacher of MTs arrohman makes students interested in learning tenses (past tense) material; it can provide understanding to students. It is in accordance with the theory of Tjokro who says that by using e- learning, students understand teaching materials faster because e- learning uses multimedia such as images, text, animation, sound and video. So the students feel that it is easier for them to learn independently. Students can access learning anywhere. In addition, Google Classroom learning is more cost-effective which means students do not need to come to school because it can be done anywhere and anytime, and it is cheaper and more efficient to reproduce, because it does not require class formalities, teaching materials can be directly studied, and mastered by students such as their enthusiasm and absorption $^{22}$.

Google Classroom has good features and is integrated with active email so that it allows students to participate which can be used to deliver materials, evaluations, and tests in one application frame. It is in accordance with theory of Yaniawati, learning with e-Learning provides benefits such as facilitating the provision of information related to lessons and also the self-development needs of students, facilitating interaction between teachers and students, as well as the interaction of one student with another student. Students can make it easier to access teaching materials, and do

\footnotetext{
${ }_{21}$ Muhaimin, Sufiah, Sugeng Listyo Prabowo. Manajemen Pendidikan. Aplikasinya dalam Penyusunan Rencana Pengembangan Sekolah/Madrasah. (Jakarta : Kencana, 2010), 26

${ }^{22}$ L. Tjokro, Sutanto. Presentasi yang Mencekam. (Jakarta: Elex Media Komputindo, 2016), 20.
} 
the tasks given, besides that students also access exam questions easily and do them within a predetermined time ${ }^{23}$.

The advantages of using Google classroom are: teachers can control more than one class of students simultaneously, make it easier for teachers to give announcements, make it easier for teachers and students, can send assignments in the form of files or videos, and more time to communicate between students and teachers. In this application all data and documents are stored properly in the space provided. Students can save documents in a special folder with a name that is easy for students to remember ${ }^{24}$. This theory related to something found in the research. In which most of students save their documents in a special folder their named to make easy to remember.

The other theory about the benefits of Google classroom is from Herman in Hammi who says that Google Classroom is an application that can create classes in cyberspace. In addition, Google Classroom can be a means of distributing assignments and assessing assignments collected by students. Google Classroom is an online learning medium that requires email, storage space and documents ${ }^{25}$. The finding showed that all students collected their assignments and assessing assignments Google classroom.

In line with Hammi, about interaction of students and teacher, and other students as Afrianti explains that the Google Classroom application is a productivity tool created to simplify and save an educator or teacher's time in managing classes and improving communication with students. With the Google Classroom application, it can make it easier for students and educators to connect with each other both inside and outside school ${ }^{26}$.

The problem faced by students of MTs arrohman when they used Google classroom were network speed, internet disruption; interference from outside, such as

${ }^{23}$ Yaniawati, Poppy. Model E-learning untuk. Meningkatkan Kompetensi Guru dan Hasil Belajar Matematika di SD Pedesaan".Jurnal Ilmiah.Bandung: Universitas Pasundan, 2016, 28

${ }^{24}$ Hikmatiar et al. Pemanfaatan Learning Manegement System Berbasis Google Classroom Dalam Pembelajaran, 2020 Jurnal Pendidikan Fisika Universitas Muhammadiyah Makassar. Volume 8 Nomor 1.79. 4.

${ }^{25}$ Hammi, Z. Implementasi Google Classroom Pada Siswa Kelas XI IPA MAN 2 Kudus. Skripsi. Semarang: Universitas Negeri Semarang, 2017), 26.

26 Afrianti, W. E. Penerapan Google Classroom pada Pembelajaran Akuntansi.Yogyakarta: Universitas Islam Indonesia: (Tidak di Publikasikan, 2018), 11.. 
the sound of family members speaking, sound of the television, people working, etc. it is in accordance with Rozaq says that the disadvantages of using Google classroom are network speed, network problems are an obstacle in using Google classroom, work assignments are more susceptible to being copied by other students, and it is not easy to control students when responding to responses submitted by the teacher ${ }^{27}$.

\section{CONCLUSION}

The English teaching and learning process including: learning objectives, learning materials, learning media, and evaluation of all components have been determined the achievement of learning on tenses material. The learning objectives are in accordance with the indicators contained in the curriculum. The material conveyed to students includes: understanding, function, and application of the past tense in sentences. Learning media using power point, pictures, and sheet of students work. The learning method used was questions and answers; the strategy used depends on the students' condition. And the evaluation results were not so good in achieving the criteria of success. That was 50\% from A class, and 34\% from B class who had reached minimum completeness criteria.

\section{BIBILIOGRAPHY}

Afrianti, W. E. Penerapan Google Classroom pada Pembelajaran Akuntansi.Yogyakarta: Universitas Islam Indonesia: Tidak di Publikasikan. 2018

Arif S. Sadiman. Peran Teknologi dalam Meningkatkan Mutu Pendidikan Dasar, Jurnal Teknodik, IV, No. 8, Mei 2000. 7.

Dewi, Prawiradilaga Salma dan Eveline, Siregar. Mozaik Teknologi Pendidikan. Jakarta : Universitas Negeri Jakarta. 2004

Djamarah, Syaiful Bahri dan Aswan Zain, Strategi Belajar Mengajar. Jakarta: Rineka Cipta. 2010

Hammi, Z. Implementasi Google Classroom Pada Siswa Kelas XI IPA MAN 2 Kudus. Semarang: Universitas Negeri Semarang. 2017

${ }^{27}$ Rozak, A., \&Albantani, A. M. Desain Perkuliahan Bahasa Arab MelaluiGoogle Classroom.Arabiyat : Jurnal Pendidikan Bahasa Arab DanKebahasaaraban,5(1), (2018). 83-102. 137. 
Hikmatiar et al. Pemanfaatan Learning Manegement System Berbasis Google Classroom Dalam Pembelajaran, 2020 Jurnal Pendidikan Fisika Universitas Muhammadiyah Makassar. Volume 8 Nomor 1.79. 4.

Ibadurrahman, Muhammad Alief. Coronavirus Asal Usul, Penyebaran, Dampak, dan Metode Pencegahan EfektifPandemi Covid-19. Altman, D.G. (1991). Sample Size. In Altman, D.G., Ed., Practical Statistics for Medical Research, Chapman \& Hall, London, 2020

Iskandar, A., Possumah, B.T., Aqbar, K.,.Peran Ekonomi dan Keuangan Sosial Islam Saat Pandemi Covid-19, Jurnal Sosial \& Budaya Syar'i, 7(7) 2020.

L. Tjokro, Sutanto. Presentasi yang Mencekam. Jakarta: Elex Media Komputindo. 2009

Li, S., Wang, Y., Xue, J., Zhao, N., \& Zhu, T.. The impact of COVID-19 epidemic declaration on psychological consequences: a study on active Weibo users. International journal of environmental research and public health, 17(6), 2020

Muhaimin, Sufi'ah, Sugeng Listyo Prabowo. Manajemen Pendidikan Aplikasinya dalam PenyusunanRencana PengembanganSekolah/Madrasah. Jakarta : Kencana. 2010

Mulvihill, RP. Technology Application to Distance Education. Paperpresented at the International Symposium on Distance Education and Open Learning organized by MONE Indonesia IDLN, SEAMOLEC, ICDE, UNDP and UNESCO, Tuban, Bali, Indonesia, 17-20 November 1997

Mulyasa. Pengembangan dan Implementasi Kurikulum 2013. Bandung : Remaja Rosdakarya, 2014

Nai, Firmina Angela. Teori Belajar dan Pembelajaran Implementasinya Dalam Pembelajaran Bahasa Indonesia Di SMP, SMA, dan SMK. Yogyakarta: Group Penerbitan CV Budi Utama. 2017

Rozak, A., \&Albantani, A. M. Desain Perkuliahan Bahasa Arab MelaluiGoogle Classroom.Arabiyat : Jurnal Pendidikan Bahasa Arab DanKebahasaaraban,5(1), 2018

Slameto. Belajar dan Faktor-Faktor yang Mempengarubinya.Jakarta: Rineka Cipta. 2010

Soekartawi, A. Haryono dan Librero.. Greater Learning Opportunities Through Distance Education: Experiences in Indonesia and The Philipines. Southeast Journal of Education. 2002

Sudjana, Dasar-dasar Proses Belajar. Bandung: Sinar Baru.2010

UU RI No 11 Tahun 2008 Informasi Dan Transaksi Elektronik. Jakarta: Sinar Grafika, 2010 
Wahyu Supriyanto, Ahmad Muhsin,. Teknologi Informasi Perpustakaan: Strategi Perencangan Perpustakaan Gitital,(Yogyakarta: Kanisius). 2008

Yaniawati, Poppy. Model E-learning untuk Meningkatkan Kompetensi Guru dan Hasil Belajar Matematika di SD Pedesaan".Jurnal Ilmiah.Bandung: Universitas Pasundan. 2016

Yew, E. H., \& Goh, K. . Problem Based Learning: An Overview of its Process and Impact on Learning. Health Professions Education, 2016

Yudi Latif, Teknologi sebagai Masalah Kebudayan, Jurnal Ulumul Qur'an, edisi No. 2, Juli 1996. 